\title{
Mysteries of Lake Copais: The Drainage - Massive Bronze Age and Hellenistic Hydraulic Engineering Works
}

\author{
Therese Ghembaza \\ Independent Researcher, Vigneux-sur-Seine, FRANCE \\ David Windell \\ Independent Researcher, Nafplio, GREECE
}

Received: 17 June 2021 - Accepted: 12 October 2021 - Published Online: 16 November 2021

\begin{abstract}
Since the draining of Lake Copais in Boeotia in the late $19^{\text {th }}$ century archaeological research has revealed Bronze Age hydraulic engineering works of such a scale as to be unique in Europe. Starting in the Middle Helladic period with dams, dikes and polders, the massive extension of the scheme in the Late Helladic period, with large canals and massive dikes, achieved the complete drainage of the lake; a feat not achieved again, despite Hellenistic attempts, until the 2oth century. In this paper we attempt to draw together research in order to tell the history of Lake Copais through the ages.
\end{abstract}

Keywords: Ancient Boeotia, Lake Copais, Bronze Age engineering, Hellenistic engineering, ancient hydraulic engineering.

\section{Introduction}

In 1886 a site forgotten to the history of Greece resurfaced almost miraculously from the water after being drowned for at least thirty-one centuries: the plain of Lake Copais in Boeotia. On the ground of the drained marsh, still crowded with a thick vegetation of reeds, enigmatic remains of dykes and canals appeared. This amazing discovery led archaeologists to search the newly drained plain for evidence of the date and methods of the earlier drainage of the lake.

Boeotia and Attica form a long peninsula, therefore bathed by the sea on three sides; but Boeotia is so isolated from marine influence by the mountain ranges which surround it that winters are harsh and summers are scorching. As the highest mountains are to the north, west and south, the plain is especially exposed to the winds from the east. Following Theophrastus $(\mathrm{V}, 12,3)$ we can also assume that before the intensive drainage the constant moisture maintained in the plain by the evaporation of the marsh was more important and mitigated the rigors of the climate.

In the $2^{\text {nd }}$ century A.D. Pausanias (Book IX) described the region of Boeotia, which lies north-west of Attica, about one hundred km from Athens (Figs. 1 and 2), commenting that the marshy Lake Copais was famous in his times for its huge and delicious eels (Pausanias, IX 24,2). In the first half of the $19^{\text {th }}$ century the inhabitants of the province began to consider draining this marshy area of $25 \mathrm{okm}^{2}$, which was very unhealthy in summer and flooded in winter. Located at

(C) Authors. Terms and conditions of Creative Commons Attribution 4.0 International (CC BY 4.0) apply. Correspondence: David Windell, Independent Researcher, Nafplio, GREECE. E-mail: 
T. Ghembaza \& D. Windell - Mysteries of Lake Copais: The Drainage - Massive Bronze Age and ...

the foot of high mountains, covered by snow in winter, the marshes of Lake Copais were indeed fed by many rivers, in order of decreasing importance: the Kephissos, ${ }^{1}$ the Melas, the Herkyne, the Phalaros and the Lophis. ${ }^{2}$ In summer, the waters of the marshes were partly reduced by evaporation, but throughout the year, their overflow drained to the east of the lake into twentythree sinkholes ("katavothres"), natural cracks in the karstic limestone. Becoming underground waters, they joined the sea in the Gulf of Euboea, some $3 \mathrm{~km}$ distant. A first attempt at drainage was carried out by a French company at the end of the $19^{\text {th }}$ century. After its partial failure, a British company undertook more significant works which made possible the final, complete drainage in the 1930's (Dean, 1937; Idol, 2018).

- Lake Copais, Boeotia, was completely drained from the Middle to Late Bronze Age.

- The hydraulic works, massive canals, dams and dikes, are unique in Europe.

- The system collapsed at the end of the Late Helladic IIIB period.

- An incomplete attempt at drainage was made in the early Hellenistic period.

- The lake was drained again in the 1890's allowing archaeological research.

2. Lake Copais before the modern drainage

In 1850, before its drainage, Emile Burnouf, a member of the French School of Archaeology of Athens, published a report on Lake Copais, as it appeared at that time, with reference to ancient authors. As he says, the lake was in the form of a square, with two bays at the west and two others at the north-eastern banks (Fig. 2). In the east, the lake was delimited by the steep flank of a limestone outcrop which separates it from the Gulf of Euboea. The marsh covered the lower part of the Kephissos valley, on an alluvial slope from southwest to northeast. Its deepest part was at the foot of the outcrop on which was sited the ancient city of Copae (modern Kastro) (Strabo, IX, 2, 27). In the riparian plain, fruit trees grew in abundance: almond, peach, hazelnut, apricot and pear, and cotton and madder (rubia tinctorum) were cultivated, but the area was subject to flooding.

The south-western bay of the lake stretched up to $7 \mathrm{~km}$ from the city of Orchomenos which was situated on the eastern end of a rocky spine, some $12 \mathrm{~m}$ above the marsh level around it (Fig. 2). The low waters of the lake covered $150 \mathrm{~km}^{2}$ and the high waters $230 \mathrm{~km}^{2}$. The flood-depth was of $6 \mathrm{~m}$ at its deepest near the city of Copae in January and February. In the north-east, the lake was separated from the Euboean Gulf by a pass at Kephalari, 35m higher than the lake level and thus it could never have joined the sea. Such land-locked basins are quite common in the Balkan peninsular and may be found at considerable heights above sea-level as "mountain-plains" such as Lassithi in Crete or as lower endorheic basins or "polje”.

\subsection{The commentary of Emile Burnouf, 1850}

Emile Burnouf noticed: "However, Lake Copais seems to have changed appearance and extent several times in ancient times. The oldest phenomenon of this kind in history is the

${ }^{1}$ We can claim no consistency in the transliteration of Greek names. We have used the "old English version" where the names are generally known but a closer transliteration from Greek where the names are less wellknown.

${ }^{2}$ The modern annual flows of these rivers are estimated as: Kephissos $179 \mathrm{hm}^{3}$, Melas $13 \mathrm{ohm}^{3}$, and the Herkyna, Pontzas and Lofis together $44 \mathrm{hm}^{3}$ (Mamassis et al., 2015). 
flood of Ogyges..$^{3}$ It had nothing in common with the deluge of the Eastern tradition, but covered the wide valley of the Cephissus and crossed the mountain passes separating Lake Hylice from the Teneric Field, as well as the crest that distinguishes this field from the plain of Thebes. All these subdivisions of the Eastern Greek basin were covered by water as well as the plains from Thebes towards Chalcis. And nothing excited more the curiosity of travelers than seeing where the alluvium ends and the limestone begins at the edge of the limestone massifs." Burnouf continued: "Boeotia was originally called Ogygia: If there was an Ogyges (and if this name is that of a man and not of a race or of a very ancient civilization), it was probably during his reign that the flood took place; it was by rain or by extraordinary snow that the level went up; but it is necessary for the waters to reach such a height that the sinkholes (katavothres) were blocked for a while." And here he quoted Strabo (IX, 2, 16) on how water sources sometimes appeared or disappeared from the surface.

Further, Strabo (IX, 2, 40) reported a popular tradition that in ancient times, the ground of the Copais basin was dry and well cultivated by the Orchomenians who had been very rich. He also noted that an engineer named Crates (Strabo, IX, 2, 18) had been ordered to carry out major construction works at the time of Alexander the Great: he was asked to "raise the dikes and to clean them! But as only channels can be cleaned, this sentence appears incomprehensible," Burnouf noticed.

\section{The first revelations of the ancient works}

The swamp was drained at the end of the $19^{\text {th }}$ century by the British Lake Copais Company. Immediately the dried lake bed revealed traces of very old works, namely dykes and canals. These observations were carefully recorded in 1892 by Michalis A. Kambanis, a Greek archaeologist who was very familiar with the region and published his observations in 1892 and 1893.

Firstly, he noted the traces of a huge project undertaken by ancient people to join the lake with the sea. He noted on the pass of Kephalari at the north-east end of the lake, attempts to cut a tunnel of more than $2 \mathrm{~km}$ in length by means of sixteen vertical shafts dug in line following the depression of the pass between the lake and the sea. These shafts, all of them almost dug to depth, and the gallery cut along one-third of the total length attest to the magnitude of these efforts (Kambanis, 1893). Secondly, at the south-east end of the lake, he found the remains of a huge trench, which had reached more than $30 \mathrm{~m}$ depth through the limestone rock, to cut through the Karditza pass which separates Lake Copais from Lake Hylike. "The traces of work started on the passes of Moriki and Anthedon to connect Lake Hylike with Lake Paralimni and this latter to the sea, remained as a draft of the present drainage works"4 Kambanis noticed. "But there are other works dating back to an unknown time and whose meaning is obscure (Fig. 3). Indeed, we see in the lake a series of strong earthworks forming dykes that so far and according to their visible parts are considered to form channels of communication through the lake's bays. They consist of an ingenious combination of high dams and trenches around the lake, that embraced all the rivers and streams draining into it, establishing channels flowing to the sinkhole region, sometimes using a single dyke running parallel to the rock edges, sometimes - and this only in the places where they had to cross the bays of the lake and where the edges were not protected by sufficiently high berms - by using two dikes running in parallel and forming a canal between them. The

3 The myth of Ogyges has many variants. According to Pausanias he was King of the Ectenes, the first people of Boeotia. One of his daughters, Alalkomene, gave her name to one of the cities in the south-west of the Copais basin.

4 It is a strange omission that no modern researchers seem to refer to these massive channels which may have been an element of the uncompleted Hellenistic drainage system. 
T. Ghembaza \& D. Windell - Mysteries of Lake Copais: The Drainage - Massive Bronze Age and ...

capacity of this work was obviously enlarged by the excavation of a large trench within the dykes. In the best-preserved parts, these dykes were 40 to $50 \mathrm{~m}$ wide at their base with a height of 1.50 $\mathrm{m}$, which leads one to assume that they have suffered collapse and general wear caused by floods in periods of heavy rains. The project's authors had cleverly divided the waters of the lake into three main channels. One that ran through the northern region, one through the central part and the last through the southern region. ${ }^{5}$ As well as these three main canals, we also see the traces of a number of secondary channels that flowed into them. All of these channels led from the tributaries towards the sinkholes taking advantage of the natural fall in that direction. Having explored the location in the east that seemed to him to be the confluence of the channels of which ten continued as a single channel leading to the main sinkholes, he found that this carefully constructed masonry was similar to the constructions at Tiryns and had many similarities with the walls of the island of Gla. "These are", he said, "the best evidence to show us, at least with some approximation, that this work relates to an era that corresponds to the floruit of the Minyans, the subjects of Minyas, King of Orchomenos.”

In 1935 the American archaeologist E. J. André Kenny took over the exploration of the Copais plain. By topographic survey, he found that the bottom of the former lake had been lowered in places by up to $3.50 \mathrm{~m}$, as a result of the compaction of the sediment and the extraction of peat by the inhabitants. He also noticed that a number of heaps of stones of 10 to $16 \mathrm{~m}$ in diameter had appeared on the surface almost in the center of the plain, south of Stroviki, probably as a result of the same phenomena.

In 1973, the Greek archaeologist T.G. Spyropoulos reported that during a small excavation near the northern dyke of the lake, he found a few shards of pottery which, according to him, belonged to an early phase of the Middle Helladic period, at the beginning of the $2^{\text {nd }}$ millennium. However, these shards only provide a terminus post quem, not necessarily a date for the construction of the dyke. Subsequent work suggests a date towards the end of the Middle Helladic period (c. $1700 \mathrm{BC}$ ) for their construction.

Lake Copais' issues had to be addressed again following the discovery in 1978 of an important Greco-Roman site in a location which, according to traditional criteria, must have once been flooded for at least part of the year. The site marked on the figures as "Xinos" which has produced both Late Helladic and Roman-Early Byzantine material with a nearby dedication naming Apollo Paiaonas. Following the final draining of the plain and the excavations made by Greek archaeologists up to 1982, we could think that the ancient kingdom(s) of the region had recovered their history. But, after four campaigns of successive excavations from May 1984 to June 1986, Pr. J. Knauss and his team of the Technische Universität of München provided important new discoveries.

In more recent years surface survey and geophysical prospection has added considerably to our knowledge of the north-eastern part of the old lake and we can hope that the central area will also yield up its secrets to similar research in the near future (Kountouri et al., 2013; Kountouri \& Lane, 2018; Lane et al., 2020).

\section{The phases of hydraulic works in the Copais basin}

In their first report Knauss et al. (1984) presented a complete study of the basin, on the historical and literary levels, as well as on its hydraulic and archaeological aspects. Thanks to

5 However, it was found that the "central canal" bordered by earth walls, much weaker than the masonry dikes of the north, south and east canals, did not pertain to the drainage system built in the Mycenaean period, but probably was part of the works started by the engineer Crates as ordered by Alexander the Great (Knauss, 1984). 
a global survey of the area using modern techniques of investigation (aerial photography and analysis of micro-photographs), the multidisciplinary team highlighted a first phase of works in the basin in the Middle Helladic period.

\subsection{The Middle Helladic period (Fig. 4)}

The Middle Helladic engineering works constituted several zones of "polders", rich zones of cultivation recovered from the marsh and protected by a system of low dams or dykes made up of only one wall of rough stone built in polygonal style. The widest of these polders consisted of the "Bay of Topolias" to the east of the ancient city of Copae including the island of Gla, bordered by only one wall of rough stone built in polygonal style. This vast zone was protected on the side of the marsh by a long rectilinear dam, which started from Cape Mytikas and joined Copae, where it bent towards the east, following for a short distance the discharge system of the lake which crossed the whole north-eastern bay to irrigate the fields, before flowing into the sinkholes. This allowed the development of a large Lower Town at Gla nearly connecting it to the site of Copae.

A similar dam closed the "Bay of Davlos" at the south-eastern edge of the lake close to the ancient city of Medeon. Further, we can suppose that the dam known as "the wall of KennyLauffer" (Kenny, 1935; Lauffer, 1979), in the north of the lake, enclosing a zone which extended from the small island of Tourloyannis to near Copae, also protected a polder around an ancient site (modern Stroviki) for which Knauss posited a possible identification as Mideia. ${ }^{6}$ However, all attempts to identify the archaeological sites with known, Homeric or even Classical names are, in the absence of inscriptions, highly speculative.

\subsection{The Late Helladic period (Fig. 5)}

The two subsequent campaigns of excavations carried out in October 1985 and May 1986 (Knauss, 1986), made considerable progress in the understanding of the drainage system. After an inundation of the $\mathrm{MH}$ polders, possibly due to a rise of the lake level following an increase of the rainfall at the end of the Middle Helladic or a failure of maintenance of the main sinkholes, a new system of land reclamation was created during the Late Helladic period (LHIIIA2 and LHIII BI) (Fig. 5). This was a real attempt to regulate the rivers and drain the whole marsh, which made it possible to control the level of the lake during the flooding of its tributaries and to completely dry the central part of the basin during the summer months at least. The installation of this powerful hydraulic engineering work could have been carried out within one or two generations.

The major element of the complex was the main northern, embanked canal which was 40m wide, $2.50 \mathrm{~m}$ in depth and some $25 \mathrm{~km}$ long and led the waters of the Kephissos and Melas rivers directly to the sinkholes. To the immediate south of this canal was a massive levee $30 \mathrm{~m}$ wide faced on both sides by Cyclopean walling. In addition to its main role in regulating the lake level and transporting drinking water, this channel could also have been used for inland navigation and for the transportation of goods to the east of the basin, from where they could be conveyed by land through the pass of Kephalari to the port of Anthedon on the Gulf of Euboea. Similarly, the wide levee could have provided a roadway for cartage of agricultural products. Knauss also suggests that in summer, when the marsh was dry, the high valley of the Melas, closed by a dam, was used as a reservoir for irrigation water (Fig. 5). In a late phase, a diversion canal was built, connected to the beginning of the main channel between Copae and Marina-Pyrgos, to supply water to the area of Gla and undoubtedly to make it possible to convey goods there by water. More recent

6 This is the modern Stroviki which has EH and LH finds, as well as two nearby forts on the hill of Tourloyianni recognized as Mycenaean (Farinetti, 2011). 
T. Ghembaza \& D. Windell - Mysteries of Lake Copais: The Drainage - Massive Bronze Age and ...

intensive survey in the area of Gla has shown LHIII rectilinear divisions of the reclaimed land as well as Cyclopean walls at the nearby sites of Ayia Marina-Pyrgos and Agios Ioannis (Kountari and Lane, 2018; Lane et al., 2020).

\subsection{Evolution of the lake and marsh in ancient times}

Very detailed topographic studies have made it possible to reconstruct, with sufficient probability, the extent and the seasonal levels of the lake at the various stages of its evolution (Ulrichs 1847, Knauss et al., 1984, Mamassis et al., 2015). These attempts at reconstitution are shown (Figs. 4 \& 5) describing the various phases of the extent of the lake, which was never as large in antiquity as it was in the $19^{\text {th }}$ century immediately before its drainage (surface area: $240 \mathrm{~km}^{2}, 110 \mathrm{~km}$ of banks).

In the Middle Helladic period (Fig. 4), at the creation of the first polders, the water level in winter reached $95 \mathrm{~m}$ above sea level giving the lake an average depth of $2.50 \mathrm{~m}$, which declined in summer to $93.5 \mathrm{~m}$. Dams approximately $1.50 \mathrm{~m}$ high thus made it possible to preserve the irrigated zones of cultivation, the polders, from winter flooding. The waters of the Melas and Kephissos were controlled by a sufficient outflow capacity of the sinkholes (katavothres) and there was no standing water. As the land was favorable to cultivation, many settlements were located on the lake banks beyond its winter limits, in particular on the southern and western banks, and it can be estimated that other vestiges of this period of the first part of the $2^{\text {nd }}$ millennium currently

rest under a layer of approximately $75 \mathrm{~cm}$ of sediments in the zone of the ancient submerged banks of the lake.

In the Late Helladic IIIA/B period (Fig. 5) the ancient zones of cultivation on polders were recovered again from the marsh and the lake was completely drained at least in the summer. In winter, one half of the water could be absorbed by the sinkholes, the other half probably remaining in the plain (maximum height of the lake: $94.5 \mathrm{~m}$; surface area $130 \mathrm{~km}^{2}, 55 \mathrm{~km}$ of banks). In summer, when the flow of the tributaries was reduced, one half of the water disappeared into the sinkholes and the other half evaporated, so that the central part of the basin was dry. A. J. Kenny (1935) located several piles of old stones in the center of the ancient lake. But these mysterious stone mounds, investigated at our request by J. Knauss in May 1987, were identified by him as simple tumuli, plundered a long time ago by tomb robbers. The few shards of pottery scattered around were too insignificant to allow a precise dating. However, the presence of burials in the center of the plain thus makes it possible to confirm that this part of the basin was quite dry during the Mycenaean era, as had already been shown (Knauss, 1986).

\section{Late Helladic IIIB/C collapse of the drainage system}

It is at the end of the Late Helladic IIIB period that this vast hydraulic complex, unique in scale in Europe at its time, was devastated and the whole basin was completely submerged by the rise of the waters in the plain. The most likely cause is detritus blocking the main sinkholes receiving the discharge from the lake but we cannot rule out deliberate breaking of dams and canal banks. The whole basin was probably quickly flooded, destroying the polders and all the low-lying cities. At the same time, excavators have shown that many of the major settlements show signs of burning suggestive of warfare. Some settlements were reoccupied in LHIIIC, e.g., Orchomenos, but most were not. In and around the Copais basin, we know of some 18 settlements of LHIIIB date but only 5 with evidence for continuation in LHIIIC. Ancient authors attributed this collapse of the drainage system to warfare between Thebes and Orchomenos with Heracles as the key 
protagonist either deliberately blocking the sinkholes or destroying dams and dikes depending on the interpretation of the ancient sources. ${ }^{7}$

However, J. M. Fossey (1988) showed that there had been a similar decline in settlement numbers in the LHIIIC period across the whole of Boeotia, so it was far from unique to the Copais basin. In 2020 Laetitia Phialon published an important review of the possible archaeological evidence for such inter-palace rivalry in Boeotia, but the events behind the collapse of both settlement and drainage works remain obscure. It is at that time, c. 1200 BC, that most of Greece entered a period of decline, which explains why only some fragments of history have reached us. The majority of these pseudo-historical accounts are in the form of legends with vague outlines, merging more or less with the mythological tales elaborated in later periods and transmitted mainly by a long oral tradition. They were saved from oblivion by historians of the Classical period who collected them from their contemporaries or re-copied them randomly in compilations from authors who had preceded them and whose works have now disappeared.

\section{Hellenistic attempts at drainage (Fig. 6)}

A remarkable "third phase" of attempted drainage of the lake seems to have been undertaken in the Hellenistic period. The main component was the unsuccessful effort to dig a huge tunnel under the pass of Kephalari to drain the waters of the lake into the Gulf of Euboea. This was a colossal undertaking. The tunnel would have been $2.2 \mathrm{~km}$ long with 16 vertical shafts to provide air, the deepest of which would have been over $56 \mathrm{~m}$ deep, all dug through solid rock (Fig. 7). The dating of this attempt to bore a tunnel under the Pass of Kephalari is a subject of controversy. According to Kambanis (1893), such a work requires developed engineering techniques and only Crates could have conceived of the project to completely drain the marsh by means of an underground artificial outflow drain under the bottom of the lake. According to Strabo (IX 2,18) the work done by Crates on the order of Alexander the Great lowered the level of the lake for some time, so the ruins of the cities would have then reappeared. But Crates' project could not be brought to completion because of disagreements among the Boeotian people. The water level rose back and the ancient cities were again submerged.

Kenny (1935), noticing that such works had been carried out in Egypt under the reign of Amenophis IV, contemporary with LHIIIA in Greece, suggested that this tunnel was the logical conclusion of the system of channels set up in the Bronze Age. However, it compares well to the great tunnel of Eupalinos on Samos which was built in the mid- $6^{\text {th }}$ century BC but which is only half the length. Perhaps the best parallels are to be found in the mining tunnels at Laurion in Attica of Hellenistic date (Chiotis, 2015) and therefore we prefer an early Hellenistic date.

As well as the tunnel, to Crates is attributed a "central" canal running east from the center of the Lake near the multi-period site of Xinos to the sinkholes of Phtelia a short distance south of the abandoned citadel of Gla. A third "southern" canal linking the Phalaros River to minor streams running into the lake from the southern hills can be traced for a short distance but it has largely been destroyed by the modern drainage works. ${ }^{8}$ Both the "central" and "southern" canals are far less strongly built than the Bronze Age northern canal and are therefore ascribed to a later

\footnotetext{
7 For details of Herakles' role from ancient authors see Graves, 1955, 121c-d.

8 Prof. Knauss claimed to have found no traces of the "right channel bank" mentioned by Kambanis (1892). The last vestiges of this ancient canal were uncovered by the Main Canal built by the French Company of Copais according to the engineer Sauvage (1846) whose first project virtually reconstructed the channel system set up by the Boeotians. The dam and channel (found by Knauss) that protected the lower town of Gla, was the last stretch of the right bank canal as it joined Copae.
} 
T. Ghembaza \& D. Windell - Mysteries of Lake Copais: The Drainage - Massive Bronze Age and ...

date. However, it should be noted that both or either would have made good sense as part of the Late Bronze Age drainage system.

Another enormous but incomplete effort, probably dated to the Hellenistic period, are the great cuttings up to $30 \mathrm{~m}$ deep which were designed to connect the eastern bay of Lake Copais to Lake Hylike and thence to Lake Paralimni, reported by Kambanis (1892), which would have been an exact precursor of the early $20^{\text {th }}$ century drainage works. If it had been completed this would have required a canal more than $1.5 \mathrm{~km}$ long and at least $90 \mathrm{~m}$ deep in places, another truly vast undertaking.

\section{Reports of the ancient authors}

Few data about the history of Boeotia in the 2nd millennium are now available. J. R. Buck in his "History of Boeotia" (1979) gathered the principal elements found in the works of minor historians (Hecataeus of Abdera, Hellanicus, Pherecydes). This history is summarized as a succession of kings, the majority without direct descent, power being transmitted randomly according to the political situation of the moment, the most influential ruler "inheriting" the throne left vacant by the disappearance of his suzerain.

According to the Boeotian tradition, one of the first sovereigns to have reigned in the area was Athamas, son of Aiolos, king of Thessaly. The biography of Athamas is relatively wellknown to us thanks to the legend of the childhood of Dionysus, grandson of Cadmus the Phoenician, King of Thebes (Pausanias, IX, 34, 5). It seems that Cadmus was a contemporary of Athamas, who had married his daughter Ino in a second wedding. The couple then adopted the child Dionysus, son of Semele a sister of Ino who had been seduced by Zeus and died, struck down wishing to contemplate the god in all his glory. Having taken under his protection this illegitimate child of Zeus, Athamas was pursued by the anger of Hera who made him kill his own son, Learchus, in a crisis of madness. Banished from his kingdom for this infanticide, Athamas obtained from Andreus, king of Orchomenos and son of the river Penae (thus a Thessalian like him), the permission to retire to Mount Laphystios and to reign over the cities of Coronea and Haliartus in the south of the plain. ${ }^{9}$

But finally, it is Minyas, to whom the Minyans owe their name, who seems to have been the most powerful of the sovereigns of Orchomenos. He had, says one, amassed immense wealth and perhaps it is to him that one would attribute the great works of engineering in the plain. This would explain the filiation with Poseidon allotted to him, this god being the lord of water par excellence. Notably, Minyas also originated from Thessaly and there seems to have been considerable Thessalian influence on the Classical religious sites around the Copais Basin, most notably Athena Itona.

Lastly, various elements of local tradition can be added. There are several couples of mythical twins in the Boeotian legends: Trophonios and Agamedes at Orchomenos, Amphion and Zethos at Thebes, Leucippe and Ephippos at Tanagra. According to Buck (1979), this may have arisen from ancient, Mycenaean worship of divine twins associated with the construction of fortified cities in the various valleys. Moreover, Onchestos had been the seat of a very ancient worship of Poseidon, who was also honored in Orchomenos. It seems that a ceremony binding Onchestos to Orchomenos, by the filiation of an Orchomenian hero with Poseidon, was part of the celebrations or that a rite of supplication existed there. This panboeotian worship of Poseidon in Onchestos is thought to have its origin in the Bronze Age. Thus, the archon of Onchestos would have had sacerdotal functions. It is also noticeable that there were many Classical shrines dedicated to Heracles in the area, for example at the source of the Melas River.

9 For further details and speculations on the myths surrounding Athamas see Graves, 1955, 70. 


\section{The sunken cities}

Various hypotheses have been proposed from ancient times for the identification of the cities submerged by the waters of the reformed lake. According to the legend five cities, at least, were drowned: Eleusis and Athenae-on-Triton according to Strabo (IX, 2, 18), which are probably in the south-west of the plain between Haliartos and Orchomenos, and Arne and Mideia (Strabo, IX, 2, 35) cited by Homer among the Boeotian cities (Iliad, II, 596), but on the location of which the ancients knew nothing more. According to Pausanias (IX, 40, 3) the ancient name of the city of Chaironeia, north of Livadia, ${ }^{10}$ at the western end of Lake Copais on the River Kephissos was Arne. However, Strabo (IX, 2, 34) says that Akraiphion at the eastern edge of Lake Copais was "named Arne by the poet" (Homer). Finally, if we may believe Strabo (IX, 2, 42), we can assume that the ancient city of Orchomenos was also submerged.

Remains of sunken cities have been located to the west of the supposed bank of the lake in the Middle Helladic period (Knauss et al., 1984) (Figs. 2 \& 4)); in particular at the mouth of the Herkyne river, in a place now named Xinos, on a low island occupying a key position in the center of the basin, the remains of a settlement were found, strewn with many shards of pottery, which made it possible to determine phases of occupation from the Middle Helladic through Late Helladic IIIB as well as Roman and early Byzantine (Fig. 8). Following Pliny the Elder (Natural History, II, 206), this place has been claimed as the ancient Boeotian Eleusis (Knauss et al., 1984; Knauss, 1986). Whatever its identity, there is no doubt regarding its key location at the center of a web of intervisibility (Fig. 8).

Other vestiges $5 \mathrm{~km}$ east of the present Orchomenos have been suggested as the ancient "lower city" mentioned by Strabo (IX, 2, 42) (marked "Old Orch" on figures). However, as this site is $5 \mathrm{~km}$ from Orchomenos itself it seems more likely that it would have had a separate name though the mobility of place-names is a well-known phenomenon in Greece. Possibly, Strabo was referring to an area just below Orchomenos but on the plain which would have been flooded and is now covered in lake sediments.

A heap of stones and some shards on the surface in the south-west of the plain has been suggested as ancient Athenai at the mouth of the river Triton. In the north of the basin, on the Melas river, on the rocky headland by the modern Pyrgos aerial photographs as well as remains on the ground also suggest a settlement dating from the Early to the Late Helladic periods which Knauss has identified as Aspledon.

During the two last campaigns of Knauss' excavations, the vestiges of the lower city of Gla, protected from the marsh by a dam or dyke were unearthed. Sadly, his survey and excavation work ended in 1986. However, since then there have been some notable advances, not in trying to identify archaeological sites with the ancient place-names, but with our understanding of the ancient hydraulic works. But in the absence of epigraphic finds on the excavated sites it remains the case that attributions of ancient place-names to sites inside the basin, Arne, Medeia, Eleusis, Athenai and Old Orchomenos remain speculation. Sadly, despite the remarkable discoveries over the last 130 years, the mythic rulers of ancient Copais have still not recovered their true homes.

\section{Conclusion}

Since the late $19^{\text {th }}$ century draining of Lake Copais, archaeologists have revealed a massive system of drainage that is unique in scale and method in Europe. The first dikes and polders were created in the Late Middle Helladic period. In the Late Helladic massive canals and

${ }_{10}$ There is a known site of Early to Late Helladic date called Magoula Balomenou, close to ancient Chaironeia, lying beside the River Kephissos, which has been suggested as Pausanias' location for Arne. 
T. Ghembaza \& D. Windell - Mysteries of Lake Copais: The Drainage - Massive Bronze Age and ...

dikes achieved the complete drainage of the lake making a vast area available for agriculture with the possibility of irrigation in the summer months. At the end of Late Helladic IIIB this whole system collapsed and the basin was catastrophically re-flooded. The cause of this disaster remains obscure. The ancients attributed it to strife between the kingdoms of Boeotia but it coincides with a general decline throughout Greece. There is evidence for a renewed attempted to drain the marshy lake in the early Hellenistic period with massive works including a long tunnel and great cuttings intended to join the lake to Lake Hylike, but this attempt was not completed. It was then left to the modern era before such massive hydraulic works could be completed.

Despite the great achievements of research to date many questions remain unanswered. The identification of the archaeological sites with the named ancient cities which were destroyed when the plain of Copais returned to a lake remains highly speculative in the absence of epigraphic evidence. The nature of the huge citadel of Gla remains obscure despite the greatest efforts and finally the causes of the collapse of the system at the end of late Helladic IIIB remain unknown. We can only hope that further work will shine yet more light on this extraordinary region.

\section{Acknowledgements}

This research did not receive any specific grant from funding agencies in the public commercial, or not-for-profit sectors.

The authors declare no competing interests.

\section{References}

Buck, J. R. (1979). A history of Boeotia. Edmonton, Alberta. University of Alberta.

Burnouf, E. (1850). Le lac Copais. Archive des Missions Scientifiques et Littéraires, 133-160.

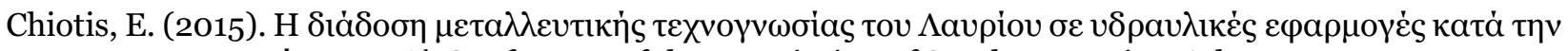
apxaiótnta. $16^{\text {th }}$ Conference of the Association of Southeast Attica, Athens.

Dean, A. J. (1937). Lake Copais, Boeotia, Greece: Its drainage and development. Journal of the Institution of Civil Engineers, Volume 5, 287-304.

Farinetti, E. (2011). Boeotian Landscapes: A GIS-based study for the reconstruction and interpretation of the archaeological datasets of Ancient Boeotia. BAR-IS 2195. Oxford.

Graves, R. (1955). The Greek myths. 70. London. Penguin Books.

Homer (1991). The Iliad, translated by R. Fagles London. Penguin.

Idol, D. (2018). The "peaceful conquest" of Lake Copais. Modern water management and environment in Greece. Journal of Modern Greek Studies, 36(1) (May 2018), 71-95. https://doi.org/10.1353/mgs.2018

Fossey, J. M. (1988). Topography and population of Ancient Boiotia. Chicago. Ares.

Kambanis, M. A. (1892). Le dessèchement du lac Copais par les Anciens. Bulletin de Correspondence Hellénique, 16, 121-137.

Kambanis, M. A. (1893). Travaux du col de Képhalari. Bulletin de Correspondence Hellénique, 17, 322-342.

Kenny, A. J. (1935). The ancient drainage of the Copais. Liverpool Annual of Archaeology and Anthropology, 22, 189-206, and Pl. LX-LXIII 
Knauss, J., Heinrich, B., \& Kalcyk, H. (1984). Die Wasserbauten der Minyer in der Kopais: die alteste Flussregulierung Europas. Institut für Wasserbau und Wassermengen Wirtschaft und Versuchanstalt für Wasserbau, Oskar von Miller Institut in Obernach, Technische Universitat München, Bericht 50, München Obernach.

Knauss, J. B. (1986). Munich Copais Expedition, Progress Report on October 1985 and May 1986 surveys. Teiresias, 16, AB/3-7.

Kountouri, E., \& Lane M. F. (2018). Myneko Annual Report. http://myneko.umbc.edu/documents/MYNEKO 2018 Annual Report-FINAL.pdf.

Kountouri, E., Petrochilos, N., Liaros, N., Oikonomou V., Koutsouyiannis, D., Mamassis, N., Zarkadoulas, N., Vött, A., Hadler, H., Henning P., \& Willershäusen. T. (2013). The Mycenean drainage works of North Copais, Greece: A new project incorporating surface surveys, geophysical research and excavation". Water Science and Technology: Water Supply, 13, 710-718.

Lane, M. F., Horsley T. J., Aravantinos V. L., \& Charami, A. (2020). The Aroura Project; Discoveries in Central Greece 2010-2014. Hesperia, 89, 413-474. https://umbc.academia.edu/MichaelLane/Papers.

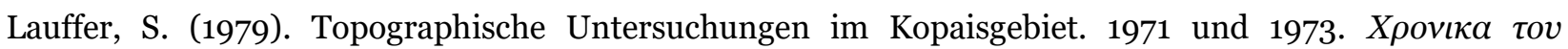

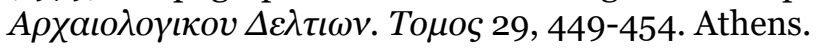

Mamassis, N., Moustakis, S., \& Zarkadoulas, N. (2015). Representing the operation of ancient reclamation works at lake Copais in Greece. Water History, 7, 271-287. https://doi.org/10.1007/s12685015-0126-x

Pausanias (1971). Pausanias. Guide to Greece, Translated by P. Levi. Vols. 1 and 2. London. Penguin.

Phialon, L. (2020). The end of a world: Local conflict and regional violence in Mycenaean Boeotia? In F. Marchand \& H. Beck (Eds.), The dancing floor of Ares: Local conflict and regional violence in Central Greece. Ancient History Bulletin, Supplemental Vol. 1, 21-45. https://hal.archivesouvertes.fr/hal-03018263/document.

Sauvage, F. (1846). Sur la géologie d'une partie de la Grèce continentale et de l'île d'Eubée. Ann. Mines, $1846,4^{\text {th }}$ series, t. X. 101-137.

Spyropoulos, T. G. (1973). Introduction to the study of the Copais area. Athens Annals of Archaeology, 6, 201-215

Strabo (1927). Translated by H. L. Jones. Strabo: The Geography. https://penelope.uchicago.edu/Thayer/E/Roman/Texts/Strabo/gB.html.

Theophrastus. (1990). De Causis Plantarum, Translated by B. Einarson \& G. K. K. Link. Harvard University. Cambridge, Mass. https://archive.org/details/decausisplantaruooo2theo/.

Ulrichs, H. N. (1840). Reisen und Forschungen in Griechenland, 1. Bremen. Theil 127. 
T. Ghembaza \& D. Windell - Mysteries of Lake Copais: The Drainage - Massive Bronze Age and ...

Appendix

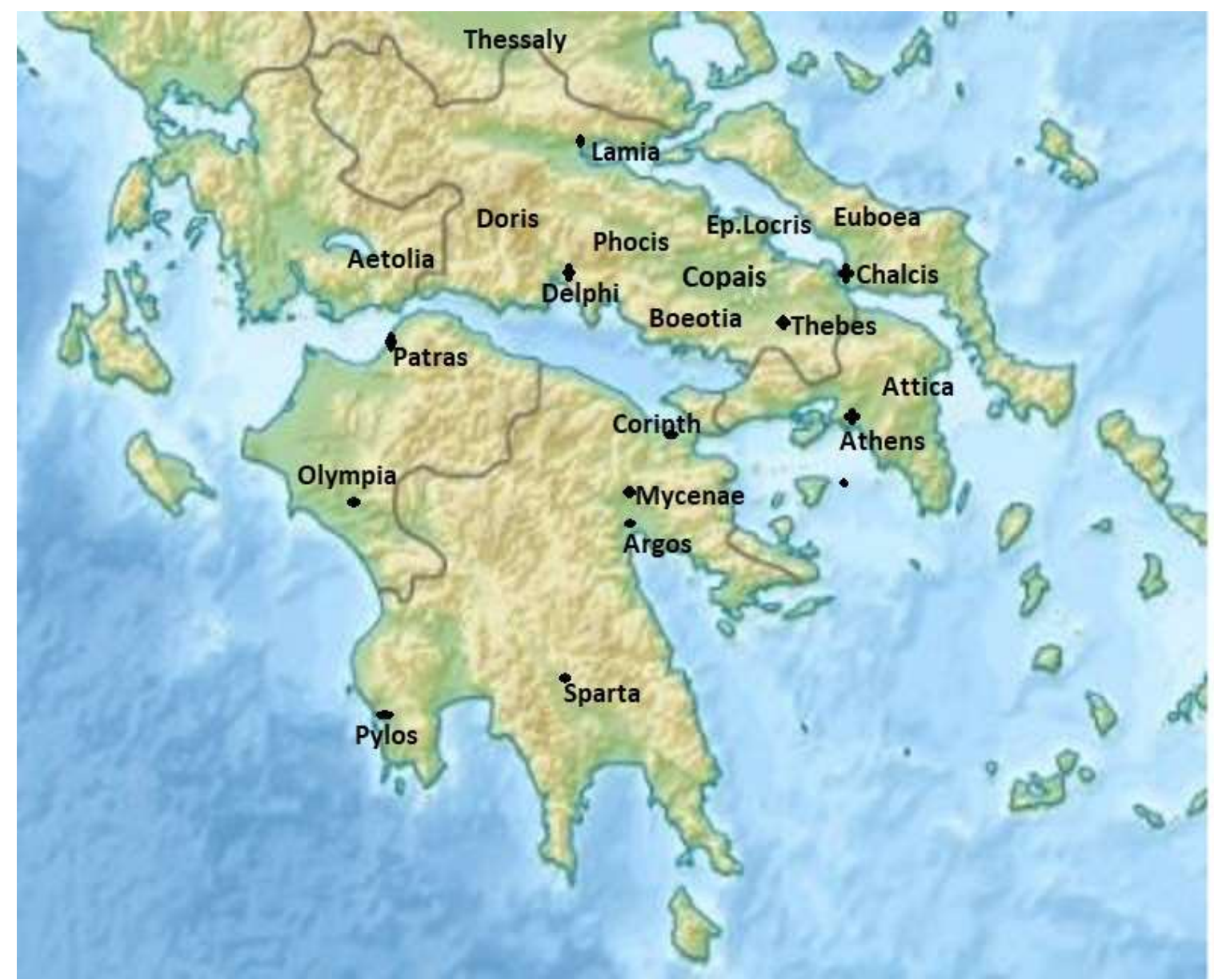

Figure 1. Location of Lake Copais, Boeotia 


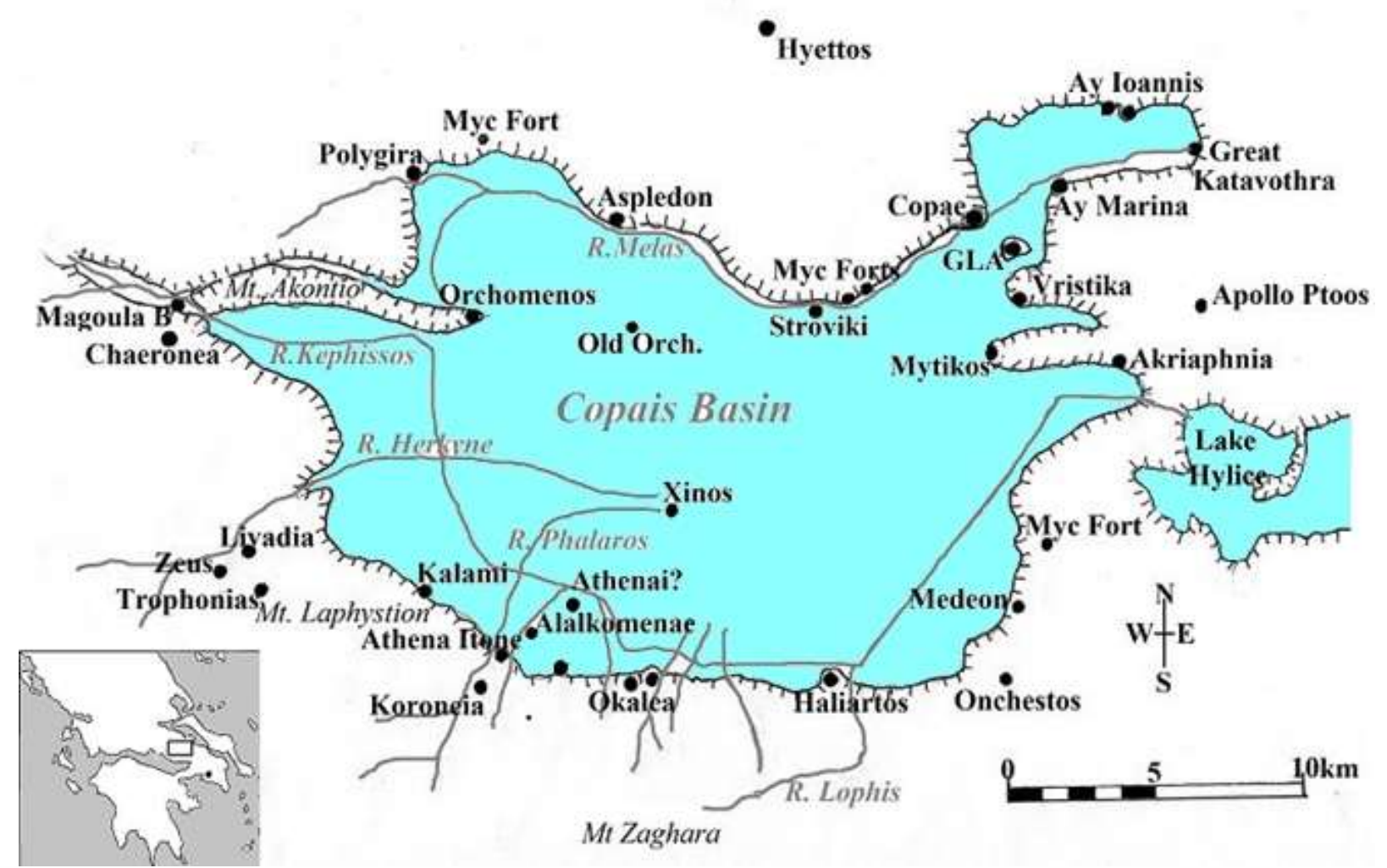

Figure 2. Archaeological sites in and around the Copais Basin 
T. Ghembaza \& D. Windell - Mysteries of Lake Copais: The Drainage - Massive Bronze Age and ...

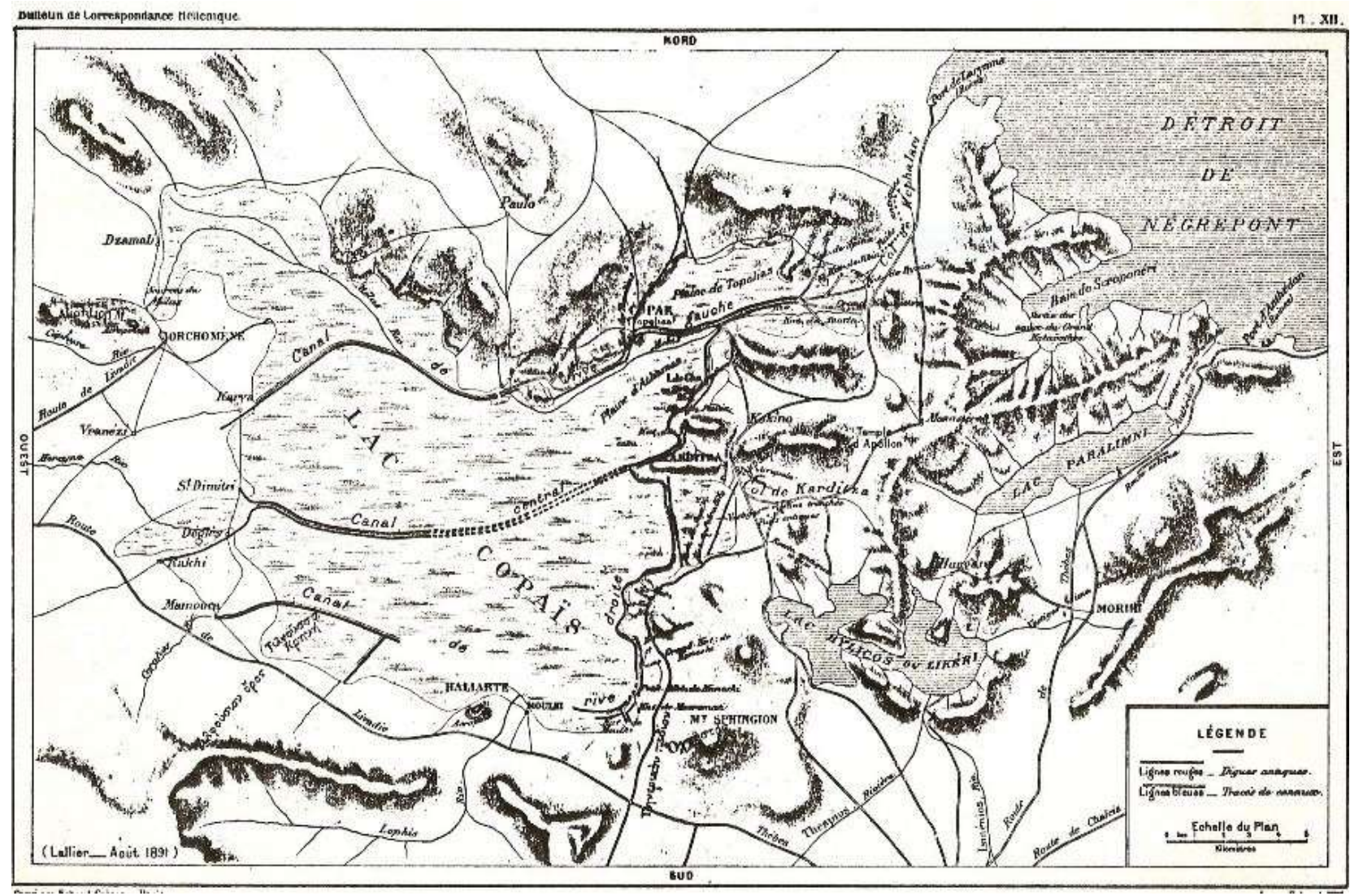

Figure 3. Map of the Copais Marsh by Lallier 1891. showing "the hydraulic works made by ancient people" 


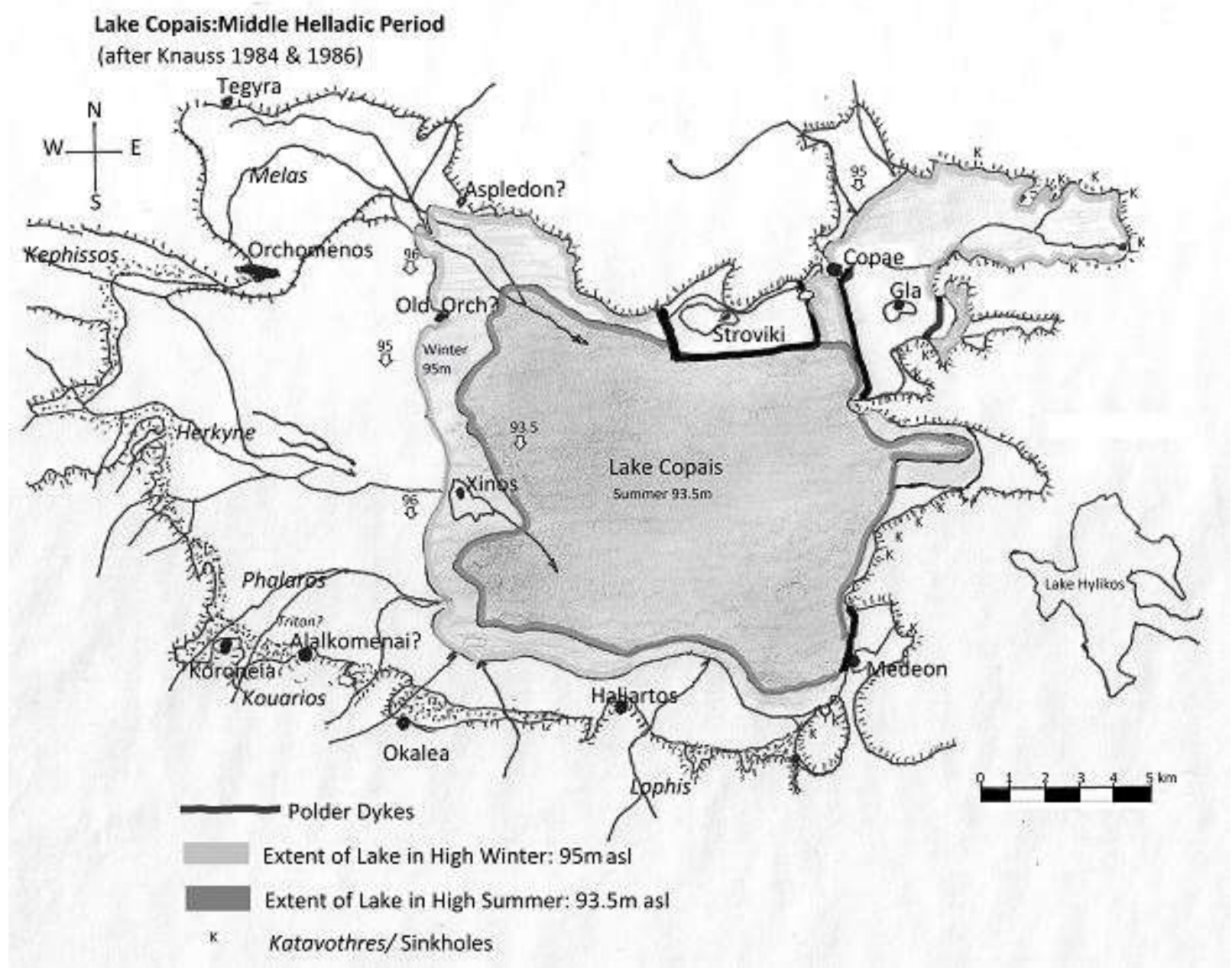

Figure 4. The Copais Basin in the Middle Helladic period (after Knauss, 1984 \& 1986) 
T. Ghembaza \& D. Windell - Mysteries of Lake Copais: The Drainage - Massive Bronze Age and ...

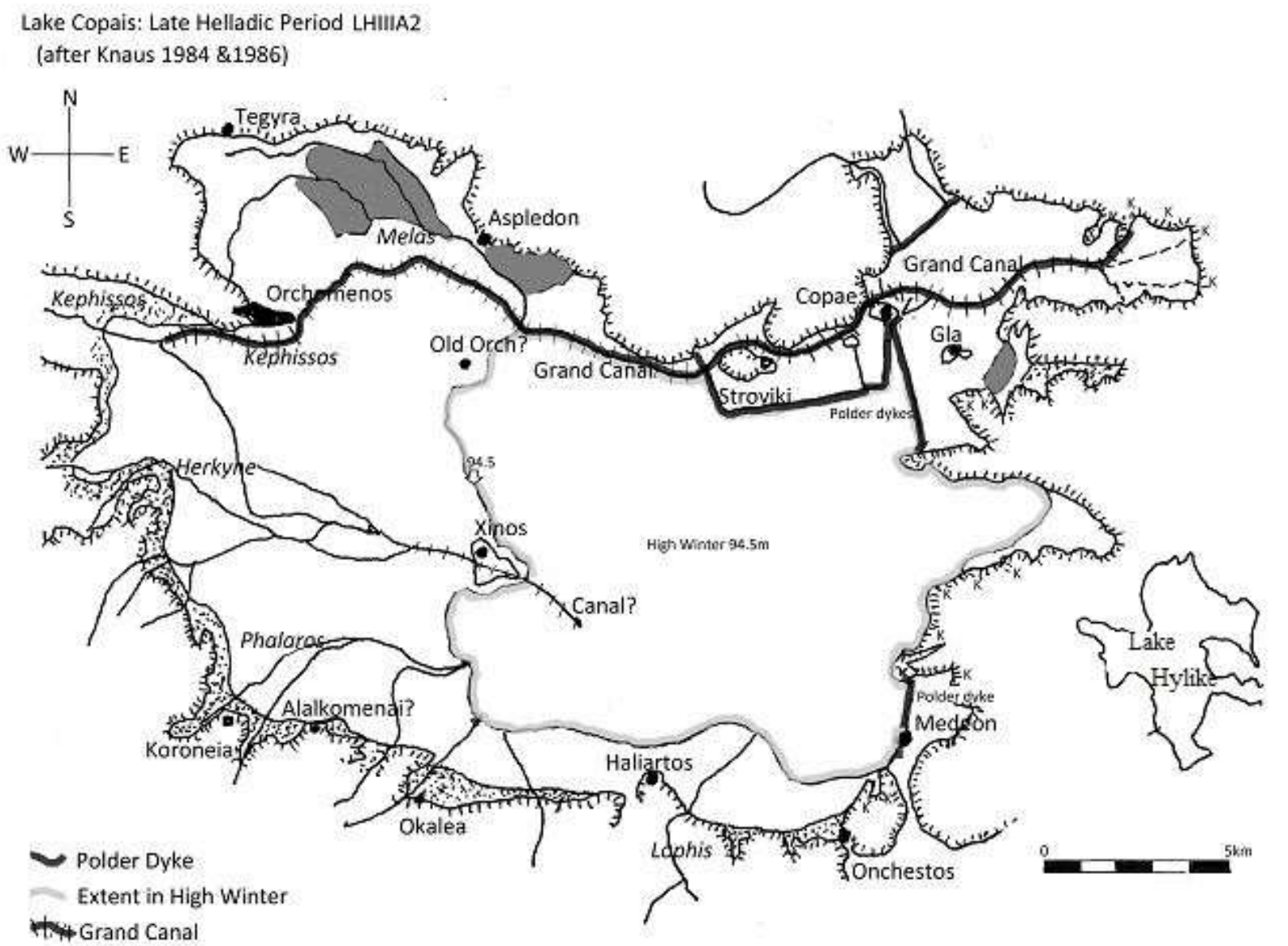

Figure 5. The Copais Basin in the Late Helladic period (LHIIIA/B) (after Knauss 1984 \& 1986) 


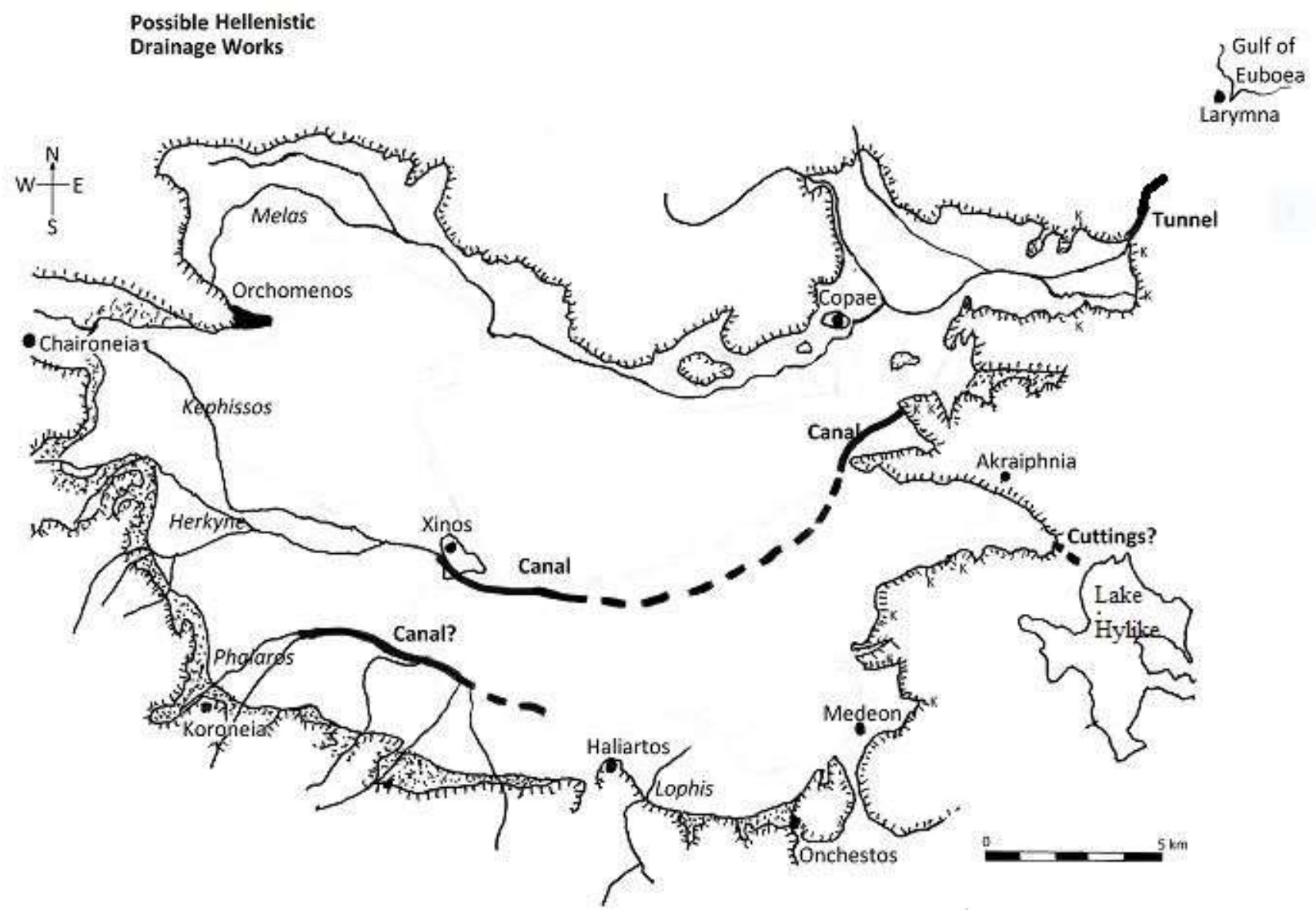

Figure 6. Attempted Drainage works probably of Hellenistic date 
T. Ghembaza \& D. Windell - Mysteries of Lake Copais: The Drainage - Massive Bronze Age and ...

\section{Tunnel under Kephalari Pass}

(after Kountouri et al. 2013)

1-16: Vertical shafts,

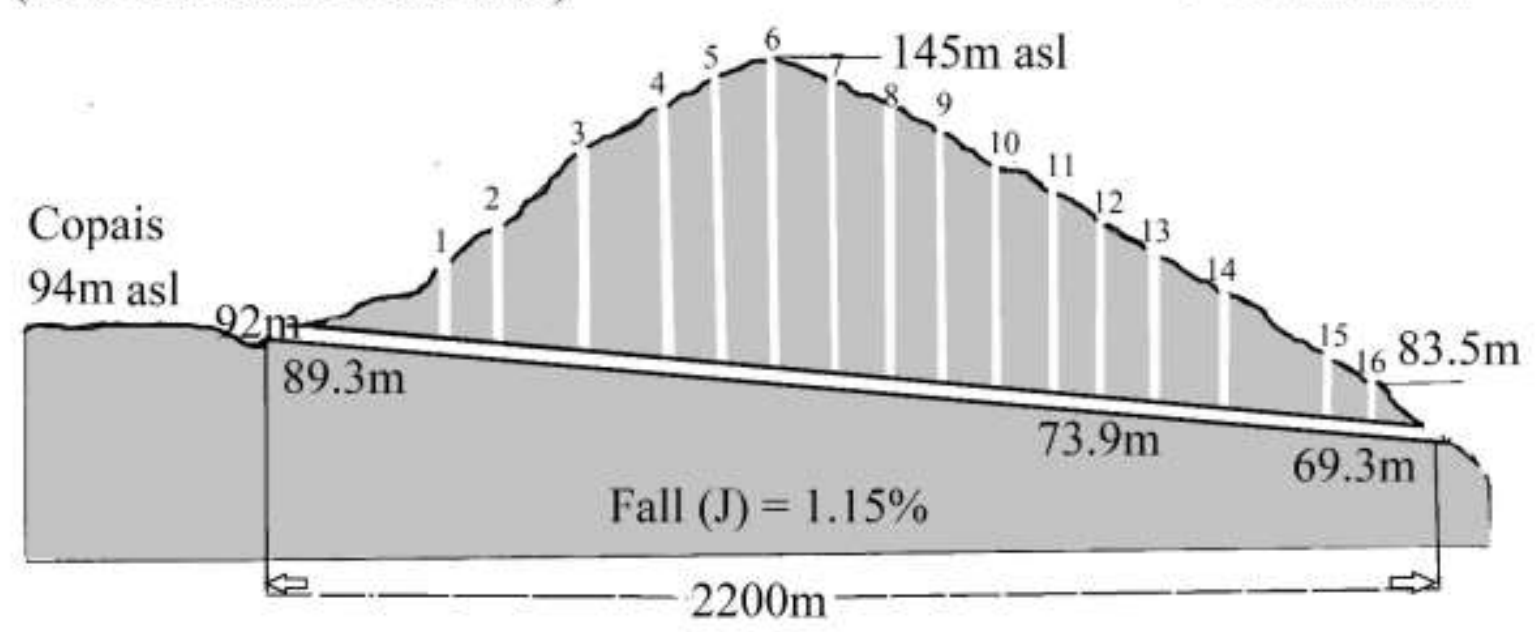

Figure 7. Cross-section of the Tunnel under the Kephalari Pass (after Kountouri et al., 2013) 